\title{
PHYSICAL AND CHEMICAL CHARACTERISTICS OF EDIBLE OFFAL FROM FREE-RANGE REARED SWALLOW-BELLY MANGALICA PIGS
}

\author{
V. TOMOVIĆa*, B. ŽLENDER ${ }^{\mathrm{b}}$, M. JOKANOVIĆa ${ }^{\mathrm{a}}$ M. TOMOVIĆc, B. ŠOJIĆa ${ }^{\mathrm{a}}$, S. ŠKALJAC \\ Ž. KeVReŠAN ${ }^{d}$, T. TASIĆd ${ }^{d}$ P. IKONIĆd ${ }^{d}$ and Đ. OKanOVIĆd \\ ${ }^{a}$ Faculty of Technology, University of Novi Sad, Bulevar cara Lazara 1, Novi Sad. Serbia \\ ${ }^{\mathrm{b} B i o t e c h n i c a l ~ f a c u l t y, ~ U n i v e r s i t y ~ o f ~ L j u b l j a n a, ~ J a m n i k a r j e v a ~ 101, ~ L j u b l j a n a . ~ S l o v e n i a ~}$ \\ "Technical school "Pavle Savić", Šajkaška 34, Novi Sad. Serbia \\ dinstitute for Food Technology, University of Novi Sad, Bulevar cara Lazara 1, Novi Sad. Serbia
}

(Received: 10 July 2014; accepted: 17 November 2014)

Physical ( $\mathrm{pH}$ and $L^{*} a^{*} b^{*}$ values) and chemical (moisture, protein, total fat, total ash, $\mathrm{K}, \mathrm{P}, \mathrm{Na}, \mathrm{Mg}, \mathrm{Ca}, \mathrm{Zn}, \mathrm{Fe}, \mathrm{Cu}$, and $\mathrm{Mn}$ ) characteristics of offal consisting of the tongue, heart, lungs, liver, spleen, kidney, brain, and spinal cord of free-range reared Swallow-Belly Mangalica pigs were determined. Many significant differences were found among mean values of quality traits. However, except for a few cases, the determined offal quality traits were in the characteristic ranges reported in the literature. Lungs were high in $\mathrm{pH}_{24 \mathrm{~h}}(\mathrm{P}<0.01)$ and $L^{*} a^{*} b^{*}$ values $(\mathrm{P}<0.01)$, as well as in moisture and $\mathrm{Na}$ concentration, and the lowest in $\mathrm{K}, \mathrm{Cu}$, and $\mathrm{Mn}$. Tongue was high in total fat, and the lowest in $\mathrm{pH}_{24 \mathrm{~h}}$, moisture $(\mathrm{P}<0.01)$, and total ash concentration. The highest levels of protein $(\mathrm{P}<0.01), \mathrm{Mg}, \mathrm{Fe}$ $(\mathrm{P}<0.05), \mathrm{Zn}(\mathrm{P}<0.01)$, and $\mathrm{Mn}(\mathrm{P}<0.01)$ and the lowest of $\mathrm{Na}$ were found in liver. The darkest colour (lowest $L^{*}$ value), highest concentration of $\mathrm{K}$, the lowest concentration of total fat and $\mathrm{Ca}$ were found in spleen. Finally, spinal cord was the highest in total ash $(\mathrm{P}<0.01), \mathrm{P}(\mathrm{P}<0.01)$, and $\mathrm{Ca}(\mathrm{P}<0.05)$ and the lowest in protein, $\mathrm{Mg}(\mathrm{P}<0.05), \mathrm{Fe}$, and $\mathrm{Zn}(\mathrm{P}<0.01)$ concentration.

Keywords: pigs, Swallow-Belly Mangalica, edible offal, physical characteristics, chemical characteristics

The Swallow-Belly Mangalica pig is an autochthonous pig breed of the region of Vojvodina (Northern Serbia) (Tomović et al., 2014), documented in the domestic animal diversity information system (DAD-IS, 2003) of the Food and Agriculture Organization (FAO).

The available scientific literature mainly describes sensory, technological, and nutritional quality of meat and lard from lean pig, but little information is available for edible offal, especially from free-range reared indigenous pig breeds (Swallow-Belly Mangalica). MéHES (1937) determined offal weight of Mangalica and its relation to their live weight, while SzABó and co-workers (2010) investigated fat composition of offal from Mangalica pigs. Also, data in most food composition tables are based on nutritional values of pork. For example, almost no data for spinal cord composition are available.

Edible offal, or variety meat, is also a form of meat, which is used as food, but which is not skeletal muscles, and in general possesses higher concentrations of some micronutrients, especially minerals and vitamins, than muscular tissue (ANDERSON, 1988; LAWRIE \& LEDWARD, 2006; Tomović et al., 2011; Tomović et al., 2013).

Meat (and edible offal) quality is the sum of all sensoric, nutritive, hygienic-toxicological, and technological factors. The nutritive factors of meat (and edible offal) quality include

\footnotetext{
* To whom correspondence should be addressed.

Phone: +381-21-485 3704; fax: +381-21-450 413; e-mail: tomovic@uns.ac.rs
}

0139-3006/\$ 20.00 C 2016 Akadémiai Kiadó, Budapest 
proteins and their composition, fats and their composition, vitamins, minerals, utilisation, digestibility, and biological value. The technological factors of meat (and edible offal) quality include $\mathrm{pH}$ value, water-holding capacity, colour, tenderness, protein content and its status, fat content and its status, and connective tissue content (HoNiKEL, 1999).

According to Serbian Regulation (1985), the edible offal of a butchered pig that are removed in dressing includes: tongue, heart, lungs, liver, spleen, kidney, brain, spinal cord, testicles, blood, part of stomach, and intestines.

The aim of this study was to determine the physical and chemical characteristics of edible offal (tongue, heart, lungs, liver, spleen, kidney, brain, and spinal cord) from freerange reared Swallow-Belly Mangalica pigs and to compare their characteristics with edible offal from lean pigs reported in the literature. It is important to provide, update, and improve regularly the nutrient composition data of edible offal.

\section{Materials and methods}

\subsection{Animals, diet, slaughter procedure, sampling, preparing, quality measurements, and quality control}

A 2-year study was performed on 15 male purebred Swallow-Belly Mangalica pigs described in detail in Tomović and co-workers (2014) and in JoKANOvić and co-workers (2013).

The following eight edible offal items were collected from each pig: tongue, heart, lungs, liver, spleen, kidney, brain, and spinal cord. Identification of the edible offal was performed according to the MEAT BuYER's Guide (NAMP, 2011). Tongue - short cut sample derived from a tongue - long cut sample by the removal of the larynx, and the tongue root was separated directly below the hyoid bones. The hyoid bones and salivary glands were eliminated, and the fat attached to the lateral and ventral surface of the tongue was trimmed. The heart was removed from the pericardium and the arteries, veins, and fat cap were trimmed from the base of the heart. Lungs were prepared by the removal of the trachea and aorta and by trimming pulmonary artery and vein. Liver sample was made from the hepatic lymph nodes incised and attached. The gall bladder, blood vessels, fat, and connective tissue attached to the liver were separated. The spleen was prepared by the removal of the splenic blood vessels. The blood vessels and ureter at their point of entry were separated from kidneys. The brain sample was made from the cerebrum (the biggest part of brain) (SPOONCER, 1988). The spinal cord sample was prepared from whole spinal cord tissue. All offal samples were packed individually in clean polyethylene bags within $1 \mathrm{~h}$ of the animal's slaughter, and conventionally chilled overnight in a chiller at $2-4{ }^{\circ} \mathrm{C}$. The edible offal were then placed to a portable refrigerator and transported by a refrigerated vehicle $\left(0-2{ }^{\circ} \mathrm{C}\right)$ to the meat laboratory of the Faculty of Technology, University of Novi Sad within $1 \mathrm{~h}$.

Physical characteristics ( $\mathrm{pH}$ value, instrumental colour $-L^{*} a^{*} b^{*}$ ), except for brain and spinal cord (data not measured), were measured on fresh offal. After the determination of physical characteristics, the edible offal was coarsely cut and homogenized (Waring 8010ES Blender, USA; capacity 1 l, speed 18000 r.p.m., duration of homogenization 10 s, temperature after homogenization $<10{ }^{\circ} \mathrm{C}$ ), vacuum packaged in polyethylene bags and stored at $-40{ }^{\circ} \mathrm{C}$ until determination of proximate (moisture, protein, total fat, and total ash) and mineral (K, $\mathrm{P}, \mathrm{Na}, \mathrm{Mg}, \mathrm{Ca}, \mathrm{Zn}, \mathrm{Fe}, \mathrm{Cu}$, and $\mathrm{Mn}$ ) composition. Determination of physical characteristics, proximate and mineral composition, and quality control programme were performed as described in detail in Tomović and co-workers $(2011 ; 2013 ; 2014)$. 


\subsection{Statistical analysis}

All data are presented as mean, standard deviation, and range. Data were analysed statistically with one-way ANOVA and post-hoc test (DunCAN's test). Levels of significance $\mathrm{P}<0.05$ and $\mathrm{P}<0.01$ were used. Statistical analysis was conducted using STATISTICA software version 10 (STATSOFT, Inc., 2011).

\section{Results and discussion}

\subsection{Physical characteristics}

Results for physical characteristics ( $\mathrm{pH}$ and instrumental colour $-L^{*} a^{*} b^{*}$ values) of edible offal from Swallow-Belly Mangalica pigs are presented in Table 1. There are significant $(\mathrm{P}<0.05)$ differences in $\mathrm{pH}$ value at $24 \mathrm{~h}$ post mortem among the particular offal items, except between the samples of tongue and heart $(\mathrm{P}>0.05)$. The lowest mean $\mathrm{pH}_{24 \mathrm{~h}}$ value was determined for tongue $\left(\mathrm{pH}_{24 \mathrm{~h}}=5.74\right)$ and heart $\left(\mathrm{pH}_{24 \mathrm{~h}}=5.85\right)$, and they were in the range characteristic for pork (5.3-5.85, HonIKEL, 1999). Lungs, liver, spleen, and kidney had ultimate mean $\mathrm{pH}$ above 6.00. The highest mean $\mathrm{pH}_{24 \mathrm{~h}}$ value was determined for lungs $\left(\mathrm{pH}_{24 \mathrm{~h}}=6.85\right)$, followed by kidney $\left(\mathrm{pH}_{24 \mathrm{~h}}=6.47\right)$, spleen $\left(\mathrm{pH}_{24 \mathrm{~h}}=6.21\right)$, and liver $\left(\mathrm{pH}_{24 \mathrm{~h}}=6.07\right)$.

Table 1. Physical characteristics of edible offal from Swallow-Belly Mangalica pigs

\begin{tabular}{|c|c|c|c|c|}
\hline \multirow{2}{*}{$\begin{array}{l}\text { Edible } \\
\text { offal }\end{array}$} & \multirow{2}{*}{$\frac{\mathrm{pH} \text { value }}{\mathrm{pH}_{24 \mathrm{~h}}}$} & \multicolumn{3}{|c|}{ Colour } \\
\hline & & $L^{*}$ (lightness) & $a^{*}$ (redness) & $b^{*}$ (yellowness) \\
\hline \multirow[t]{2}{*}{ Tongue } & $5.74 \pm 0.05^{\mathrm{eD}}$ & $46.41 \pm 1.93^{\mathrm{bB}}$ & $20.39 \pm 1.24^{\mathrm{bB}}$ & $7.53 \pm 1.07^{\mathrm{dCD}}$ \\
\hline & $(5.66-5.78)$ & $(43.18-47.96)$ & $(18.71-21.95)$ & $(6.02-9.05)$ \\
\hline \multirow[t]{2}{*}{ Heart } & $5.85 \pm 0.15^{\mathrm{eD}}$ & $34.04 \pm 1.26^{\mathrm{dD}}$ & $20.89 \pm 0.90^{\mathrm{bB}}$ & $6.04 \pm 0.63^{\mathrm{dD}}$ \\
\hline & $(5.76-6.12)$ & $(32.65-35.76)$ & $(19.75-21.83)$ & $(5.22-6.80)$ \\
\hline \multirow[t]{2}{*}{ Lungs } & $6.85 \pm 0.04^{\mathrm{aA}}$ & $52.74 \pm 3.77^{\mathrm{aA}}$ & $30.27 \pm 0.78^{\mathrm{aA}}$ & $14.44 \pm 2.37^{\mathrm{aA}}$ \\
\hline & $(6.80-6.91)$ & $(49.34-58.82)$ & $(29.18-31.11)$ & (11.69-17.79) \\
\hline \multirow[t]{2}{*}{ Liver } & $6.07 \pm 0.10^{\mathrm{dC}}$ & $29.56 \pm 1.81^{\mathrm{eE}}$ & $14.16 \pm 1.42^{\mathrm{cC}}$ & $9.12 \pm 0.77^{\mathrm{cBC}}$ \\
\hline & $(5.96-6.21)$ & $(26.84-31.33)$ & $(12.55-15.62)$ & $(8.29-10.06)$ \\
\hline \multirow[t]{2}{*}{ Spleen } & $6.21 \pm 0.08^{\mathrm{cC}}$ & $27.04 \pm 0.98^{\mathrm{eE}}$ & $19.45 \pm 1.33^{\mathrm{bB}}$ & $6.87 \pm 0.64^{\mathrm{dD}}$ \\
\hline & $(6.15-6.34)$ & $(25.84-28.14)$ & $(17.51-21.10)$ & $(6.15-7.82)$ \\
\hline \multirow[t]{2}{*}{ Kidney } & $6.47 \pm 0.05^{\mathrm{bB}}$ & $41.32 \pm 2.20^{\mathrm{cC}}$ & $13.87 \pm 1.79^{\mathrm{cC}}$ & $11.19 \pm 0.70^{\mathrm{bB}}$ \\
\hline & $(6.40-6.53)$ & $(38.81-44.19)$ & $(12.03-16.87)$ & $(10.42-12.15)$ \\
\hline$P$ value & $<0.001$ & $<0.001$ & $<0.001$ & $<0.001$ \\
\hline
\end{tabular}

abcde indicates significant difference within column at $\mathrm{P}<0.05 ;{ }^{\mathrm{ABCDE}}$ indicates significant difference within column at $\mathrm{P}<0.01$. 
According to FLOREK and co-workers (2011), the distinction made between offal as derived mainly from organ tissue and those originating from muscular tissue is crucial because of differences in their potential to sustain quality.

The post-mortem $\mathrm{pH}$ of meat is determined by the amount of lactic acid produced from glycogen during anaerobic glycolysis (LAWRIE \& LEDWARD, 2006). With the exception of liver, offal contains low levels of carbohydrates, being quite similar to or lower than lean meat. The liver normally has about 5.3\% carbohydrate, mainly as glycogen (SAVELL \& Pearson, 1988). The $\mathrm{pH}$ is a very important criterion for meat and meat products quality. An ultimate $\mathrm{pH}$ above 5.85 shortens the shelf life (Gill, 1988; Honikel, 1999; Lawrie \& Ledward, 2006).

Instrumental colour measurements for lightness ( $L^{*}$ value), redness ( $a^{*}$ value), and yellowness $\left(b^{*}\right.$ value) were significantly affected by the type of offal (Table 1$)$. There were significant $(\mathrm{P}<0.01)$ differences in $L^{*}$ value among the particular offal items, except between spleen and liver $(\mathrm{P}>0.05)$. Spleen and liver had the lowest mean $L^{*}$ values, i.e. darker colour ( $L^{*}=27.04$ and 29.56, respectively), followed by heart $\left(L^{*}=34.04\right)$, kidney $\left(L^{*}=41.32\right)$, tongue $\left(L^{*}=46.41\right)$, and lungs $\left(L^{*}=52.74\right)$. The mean redness $\left(a^{*}\right.$ value) was significantly $(\mathrm{P}<0.01)$ the highest for lungs $\left(a^{*}=30.27\right)$. Heart, tongue, and spleen were the next highest in redness ( $a^{*}$ value), ranging from 17.51 to $21.95(\mathrm{P}>0.05)$, followed by liver and kidney in the range of 12.03-16.87 $(\mathrm{P}>0.05)$, with a significant $(\mathrm{P}<0.01)$ difference between these two groups. Lungs had the highest mean yellowness $\left(b^{*}=14.44\right)$, followed by kidney $\left(b^{*}=11.19\right)$ and liver $\left(b^{*}=9.12\right)$, with a significant difference between them $(\mathrm{P}<0.05)$. Significantly $(\mathrm{P}<0.05)$ the lowest yellowness $\left(b^{*}\right.$ value $)$ was determined for tongue, spleen, and heart, in the range of 5.22-9.05.

\subsection{Proximate composition}

The values for moisture, protein, total fat, and total ash concentrations in edible offal of Swallow-Belly Mangalica pigs are presented in Table 2. The proximate composition was significantly influenced by the type of offal. Lungs, kidney, and spleen had moisture concentration higher than $790 \mathrm{~g} \mathrm{~kg}^{-1}$, whereas for heart it was in the range from 748.0 to $768.6 \mathrm{~g} \mathrm{~kg}^{-1}$. Tongue and spinal cord were significantly $(\mathrm{P}<0.01)$ the lowest in moisture level $\left(<690 \mathrm{~g} \mathrm{~kg}^{-1}\right)$, and significantly $(\mathrm{P}<0.01)$ the highest in total fat $\left(>160 \mathrm{~g} \mathrm{~kg}^{-1}\right)$. The lowest total fat concentration was found for spleen $\left(<20 \mathrm{~g} \mathrm{~kg}^{-1}\right)$. The protein level in all analysed offal samples was less than $200 \mathrm{~g} \mathrm{~kg}^{-1}$. Liver had significantly $(\mathrm{P}<0.01)$ the highest $(>180 \mathrm{~g}$ $\left.\mathrm{kg}^{-1}\right)$, whereas brain and spinal cord had significantly $(\mathrm{P}<0.01)$ the lowest $\left(\leq 110 \mathrm{~g} \mathrm{~kg}^{-1}\right)$ protein concentration. Spinal cord had significantly $(\mathrm{P}<0.01)$ the highest $\left(>16.0 \mathrm{~g} \mathrm{~kg}^{-1}\right)$ ash concentration of all edible offal items, while heart and tongue had significantly $(\mathrm{P}<0.05)$ the lowest ash concentration.

The proximate composition of analysed offal is similar to the values reported for the pig edible offal composition tables (LAWRIE \& LEDWARD, 2006; Italy - INRAN, 2007; EUROPEAN Institute of Oncology, 2008; Denmark - National Food Institute, 2009; Finland - National Institute for Health and Welfare, 2009; USA - The US Department of Agriculture's, 2009).

\subsection{Mineral composition}

Mineral (K, P, Na, Mg, Ca, Fe, Zn, Cu, and Mn) concentrations of edible offal for SwallowBelly Mangalica pigs are presented in Table 3. The mineral composition was significantly 
Table 2. Proximate composition $\left(\mathrm{g} \mathrm{kg}^{-1}\right)$ of edible offal from Swallow-Belly Mangalica pigs

\begin{tabular}{|c|c|c|c|c|}
\hline Edible offal & Moisture & Protein & Total fat & Total ash \\
\hline \multirow[t]{2}{*}{ Tongue } & $635.5 \pm 20.0^{\mathrm{fF}}$ & $150.7 \pm 9.5^{\mathrm{cdC}}$ & $204.9 \pm 28.2^{\mathrm{aA}}$ & $7.9 \pm 0.4^{\mathrm{fF}}$ \\
\hline & $(611.8-663.6)$ & (139.9-161.7) & $(164.2-238.9)$ & $(7.4-8.3)$ \\
\hline \multirow[t]{2}{*}{ Heart } & $759.4 \pm 8.8^{\mathrm{cC}}$ & $157.0 \pm 10.3^{\mathrm{cC}}$ & $73.2 \pm 8.3^{\mathrm{bB}}$ & $8.7 \pm 0.9^{\mathrm{fEF}}$ \\
\hline & $(748.0-768.6)$ & $(141.3-169.7)$ & $(63.1-85.2)$ & $(7.4-9.5)$ \\
\hline \multirow[t]{2}{*}{ Lungs } & $816.7 \pm 23.4^{\mathrm{aA}}$ & $144.1 \pm 15.1^{\mathrm{dC}}$ & $24.8 \pm 7.9^{\mathrm{cdC}}$ & $9.8 \pm 1.5^{\mathrm{eE}}$ \\
\hline & $(790.5-852.0)$ & $(120.4-159.9)$ & $(17.2-38.1)$ & $(7.3-11.1)$ \\
\hline \multirow[t]{2}{*}{ Liver } & $721.8 \pm 2.5^{\mathrm{dD}}$ & $188.5 \pm 6.5^{\mathrm{aA}}$ & $31.1 \pm 1.9^{\mathrm{cdC}}$ & $15.2 \pm 0.5^{\mathrm{bB}}$ \\
\hline & $(718.3-724.0)$ & (183.7-199.7) & $(28.7-33.1)$ & $(14.7-15.7)$ \\
\hline \multirow[t]{2}{*}{ Spleen } & $793.7 \pm 1.7^{\mathrm{bB}}$ & $171.5 \pm 3.1^{\mathrm{bB}}$ & $18.0 \pm 1.2^{\mathrm{dC}}$ & $13.6 \pm 0.6^{\mathrm{cC}}$ \\
\hline & $(790.9-795.5)$ & $(166.5-174.3)$ & $(16.8-19.6)$ & $(12.6-14.2)$ \\
\hline \multirow[t]{2}{*}{ Kidney } & $801.5 \pm 5.4^{\mathrm{abAB}}$ & $147.9 \pm 4.8^{\mathrm{cdC}}$ & $37.9 \pm 6.6^{\mathrm{cC}}$ & $12.0 \pm 0.5^{\mathrm{dD}}$ \\
\hline & $(792.9-807.3)$ & $(141.0-152.5)$ & $(32.8-45.6)$ & $(11.5-12.5)$ \\
\hline \multirow[t]{2}{*}{ Brain } & $764.6 \pm 7.4^{\mathrm{cC}}$ & $107.1 \pm 1.9^{\mathrm{eD}}$ & $87.1 \pm 10.3^{\mathrm{bB}}$ & $14.3 \pm 0.6^{\mathrm{bcBC}}$ \\
\hline & $(756.2-773.3)$ & $(105.5-109.6)$ & $(76.9-98.1)$ & $(13.8-15.1)$ \\
\hline \multirow[t]{2}{*}{ Spinal cord } & $675.2 \pm 6.4^{\mathrm{eE}}$ & $105.7 \pm 3.3^{\mathrm{eD}}$ & $200.7 \pm 2.6^{\mathrm{aA}}$ & $17.3 \pm 0.7^{\mathrm{aA}}$ \\
\hline & $(667.8-682.5)$ & (101.9-110.0) & (196.2-203.1) & $(16.6-18.2)$ \\
\hline$P$ value & $<0.001$ & $<0.001$ & $<0.001$ & $<0.001$ \\
\hline
\end{tabular}

abcdef indicates significant difference within column at $\mathrm{P}<0.05$; ${ }^{\mathrm{ABCDEF}}$ indicates significant difference within column at $\mathrm{P}<0.01$.

influenced by the type of offal. The concentration of minerals in tongue, heart, and kidney decreased as $\mathrm{K}>\mathrm{P}>\mathrm{Na}>\mathrm{Mg}>\mathrm{Ca}>\mathrm{Fe}>\mathrm{Zn}>\mathrm{Cu}>\mathrm{Mn}$. Likewise, the concentration of minerals in liver and spleen decreased as $\mathrm{K}>\mathrm{P}>\mathrm{Na}>\mathrm{Fe}>\mathrm{Mg}>\mathrm{Ca}>\mathrm{Zn}>\mathrm{Cu}>\mathrm{Mn}$, whereas for lungs and brain it decreased as $\mathrm{K}>\mathrm{P}>\mathrm{Na}>\mathrm{Ca}>\mathrm{Mg}>\mathrm{Fe}>\mathrm{Zn}>\mathrm{Cu}>\mathrm{Mn}$. Similarly, the concentration of minerals in spinal cord decreased as $\mathrm{P}>\mathrm{K}>\mathrm{Na}>\mathrm{Ca}>\mathrm{Mg}>\mathrm{Fe}>\mathrm{Zn}>\mathrm{Cu}>\mathrm{Mn}$. Significantly $(\mathrm{P}<0.01)$ the highest mean $\mathrm{K}$ concentration was found for spleen $\left(4638 \mathrm{mg} \mathrm{kg}^{-1}\right)$. The spinal cord had significantly $(\mathrm{P}<0.01)$ the highest mean $\mathrm{P}$ concentration $\left(5014 \mathrm{mg} \mathrm{kg}^{-1}\right)$, followed by brain, liver, and spleen (3542, 3455, and $3014 \mathrm{mg} \mathrm{kg}^{-1}$, respectively), and kidney, lungs, tongue, and heart $\left(2258,2087,1730\right.$, and $1714 \mathrm{mg} \mathrm{kg}^{-1}$, respectively). Concentrations of $\mathrm{Na}$ in four offal types including lungs, kidney, spinal cord, and brain were in the range of 1191$1945 \mathrm{mg} \mathrm{kg}^{-1}$, and they were significantly $(\mathrm{P}<0.01)$ higher than in the other four offal types, where they were in the range of 691-1024 $\mathrm{mg} \mathrm{kg}^{-1}$. In the spinal cord, significantly $(\mathrm{P}<0.05)$ the lowest mean concentration of $\mathrm{Mg}\left(83 \mathrm{mg} \mathrm{kg}^{-1}\right)$ and significantly $(\mathrm{P}<0.05)$ the highest mean concentration of $\mathrm{Ca}\left(260.2 \mathrm{mg} \mathrm{kg}^{-1}\right)$ were determined. Among the offal, the mean $\mathrm{Fe}$ concentration was significantly $(\mathrm{P}<0.01)$ the highest for liver $\left(335.8 \mathrm{mg} \mathrm{kg}^{-1}\right)$, followed by 
spleen $\left(274.9 \mathrm{mg} \mathrm{kg}^{-1}\right)$, but with significant difference $(\mathrm{P}<0.05)$ between these offal types. Otherwise, it was in the range of $15.5-75.0 \mathrm{mg} \mathrm{kg}^{-1}$. The liver had significantly $(\mathrm{P}<0.01)$ the highest mean concentration of $\mathrm{Zn}\left(53.4 \mathrm{mg} \mathrm{kg}^{-1}\right)$, followed by spleen $\left(31.5 \mathrm{mg} \mathrm{kg}^{-1}\right)$, kidney (22.4 $\left.\mathrm{mg} \mathrm{kg}^{-1}\right)$, tongue $\left(21.3 \mathrm{mg} \mathrm{kg}^{-1}\right)$, lungs $\left(20.9 \mathrm{mg} \mathrm{kg}^{-1}\right)$, heart $\left(16.1 \mathrm{mg} \mathrm{kg}^{-1}\right)$, brain $(15.6$ $\left.\mathrm{mg} \mathrm{kg}^{-1}\right)$, and spinal cord $\left(6.7 \mathrm{mg} \mathrm{kg}^{-1}\right)$. Significantly $(\mathrm{P}<0.05)$ higher mean $\mathrm{Cu}$ concentration was determined in kidney, liver, heart, and brain (3.93,3.65, 3.20, $3.19 \mathrm{mg} \mathrm{kg}^{-1}$, respectively). Significantly $(\mathrm{P}<0.05)$ the lowest mean $\mathrm{Cu}$ concentration was found in lungs $\left(1.18 \mathrm{mg} \mathrm{kg}^{-1}\right)$. The mean Mn concentration was significantly $(\mathrm{P}<0.01)$ the highest for liver $\left(2.67 \mathrm{mg} \mathrm{kg}^{-1}\right)$, followed by that for kidney $\left(1.23 \mathrm{mg} \mathrm{kg}^{-1}\right)$. In the other offal types, it ranged from 0.27 to $0.58 \mathrm{mg} \mathrm{kg}^{-1}$, without significant difference $(\mathrm{P}>0.05)$ between them.

Except in a few cases, the mineral composition of the offal analysed in this study was similar to the values reported for the pig edible offal composition tables (ANDERSON, 1988; Lawrie \& LedWARd, 2006; Italy - INRAN, 2007; European Institute of OnCOlogy, 2008; Denmark - National Food Institute, 2009; Finland - National Institute for Health and Welfare, 2009; USA - The US Department of Agriculture's, 2009; Tomović et al., 2011; 2013). According to GreEnfield and Southgate (2003), meat (edible offal) exhibits natural variations in the amounts of nutrients contained, and the limits of the natural nutrient variations are not defined.

\section{Conclusions}

Interest by consumers in the so-called "natural", "bio", or "organic" animal products has been increasing. Therefore, offal from pig production systems, in which pigs are free-range reared and fed on natural feeds with no growth promoters and antibiotics, is an important field of interest.

Many significant differences were found in the mean values of quality traits among the analysed offal items, which could be mainly explained by a wide range of the present tissue types. Thus, offals have been highly variable in their nutritional and technological quality.

Based on obtained data, consumer knowledge, mainly of the nutrient content of specific offals, could be increased, since offals are usually prepared for the table rather than for use in manufactured meat products. Additionally, more studies are needed to provide a better knowledge about edible offal characteristics, especially including eating quality of some cooked offal.

Research was financially supported by the Ministry of Education, Science and Technological Development, Republic of Serbia, project TR31032. These results are also part of the project No 114-451-1016/2014 (Improvement of meat quality from indigenous and modern pig breeds produced in Vojvodina for the production of traditional dry fermented sausages and dry cured meat products), which is financially supported by the Provincial Secretariat for Science and Technological Development, Autonomous Province of Vojvodina, Republic of Serbia, and the project No 651-03-1251/2012-09/45 (Characterization of sensory and physicochemical attributes of protected traditional dry fermented meat products from Slovenia and Serbia) within the Serbia - Slovenia science technology cooperation for years 2012-2013. 


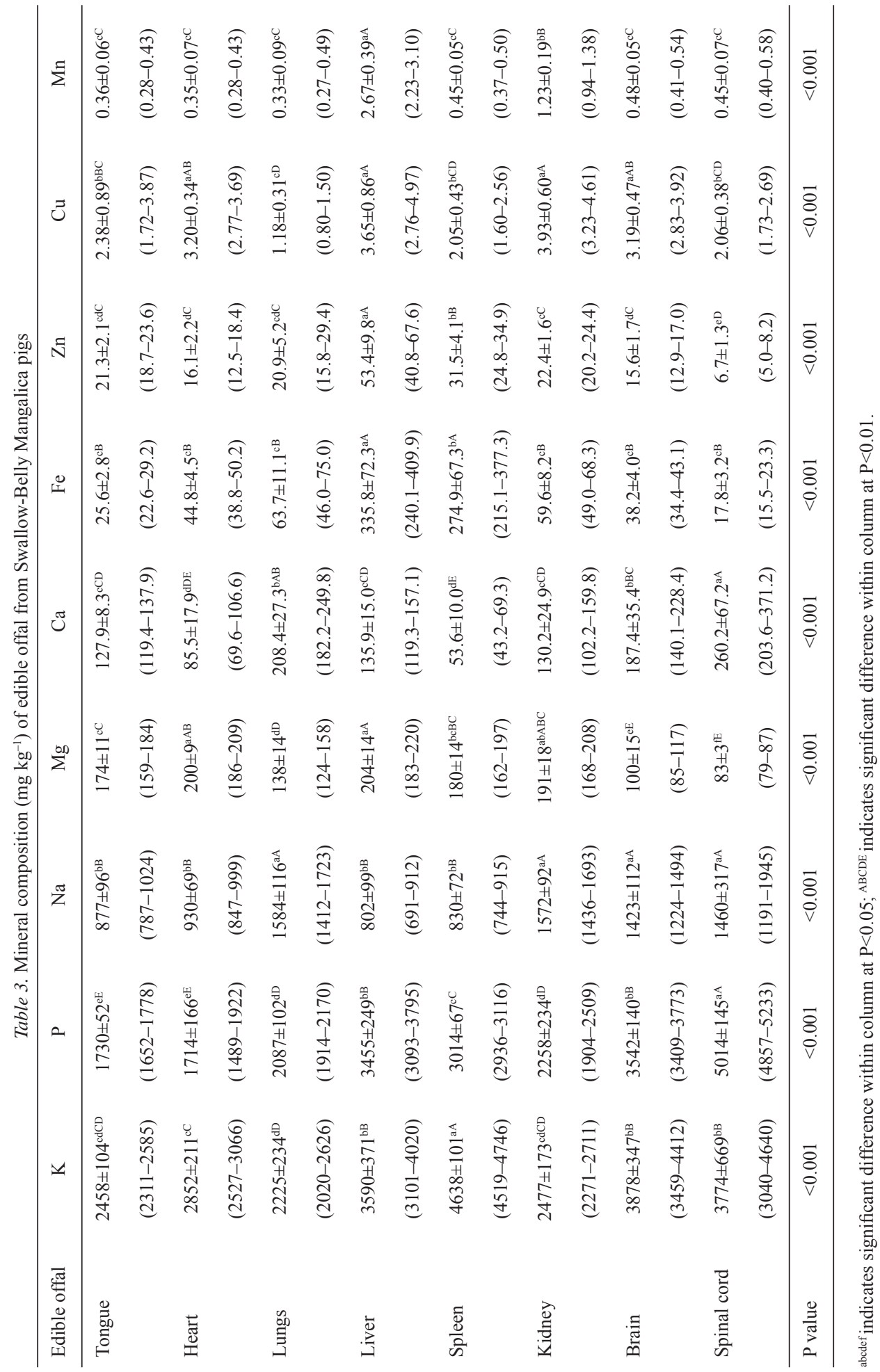




\section{References}

Anderson, B.A. (1988): Composition and nutritional value of edible meat by-products. -in: Pearson, A.M. \& Dutson, T.R. (Eds): Edible meat by-products, Advances in meat research. Vol. 5, Elsevier Science Publishers Ltd, London, UK. pp. 15-45.

DAD-IS (2003): Domestic animal diversity information system. Available at: http://dad.fao.org/.

European InstituTE of ONCOLOGY (2008): Food composition database for epidemiological studies in Italy. Available at: http://www.ieo.it/bda2008/homepage.aspx.

Florek, M., Zitwińczuk, Z., Skalecki, P., Kedzierska-Matysek, M. \& Grodzicki, T. (2011): Chemical composition and inherent properties of offal from calves maintained under two production systems. Meat Sci., 90, 402409.

Gill, C.O. (1988): Microbiology of edible meat by-products. -in: PEArson, A.M. \& Dutson, T.R. (Eds): Edible meat by-products, Advances in meat research. Vol. 5, Elsevier Science Publishers Ltd, London, UK, pp. 47-82.

Greenfield, H. \& Southgate, D.A.T. (2003): Food composition data: Production, management and use. (2nd ed). FAO, Rome, Italy, 288 pages

Honikel, K.O. (1999): Biochemical and physico-chemical characteristics of meat quality. Meat Technol., 40, 105123.

INRAN (2007): Istituto Nazionale di Ricerca per gli Alimenti e la Nutrizione, Banca Dati di Composizione degli Alimenti. Available at: http://www.inran.it/646/tabelle_di_composizione_degli_alimenti.html

Jokanović, M.R., Tomović, V.M., Šojić, B.V., ŠKaljac, S.B., Tasić, T.A., Ikonić, P.M. \& Kevrešan, Ž.S. (2013): Cadmium in meat and edible offal of free-range reared Swallow-Belly Mangalica pigs from Vojvodina (northern Serbia). Food Addit. Contam. B., 6, 98-102.

Lawrie, R.A. \& Ledward, D.A. (2006): Lawrie's meat science. (7th ed). Woodhead Publishing Limited, Cambridge, England, pp. 175, 345 .

MéHes, Gy. (1937): A magyar mangalica és az angol hússertés súlyarányai (The weight ratio of Hungarian Mangalica and Yorkshire pig). Dissertation, Budapest, Hungary, 23 pages.

National Food Institute Denmark - Technical University of Denmark (2009): Danish food composition data. Meat and meat products. Available at: http://www.foodcomp.dk/v7/fcdb_grpsearchres.asp?MainGrp=07.

National Institute for Health and Welfare. FINELI (2009): Finnish food composition database. Available at: http://www.fineli.fi/index.php?lang=en.

NAMP (2011): The meat buyer's guide. (7th ed.) North American Meat Processors Association, Reston, USA.

SAVEll, J.W. \& PeArson, A.M. (1988): Packaging, transportation and distribution of edible meat by-products. -in: Pearson, A.M. \& Dutson, T.R. (Eds) Edible meat by-products. Advances in meat research. Vol. 5, Elsevier Science Publishers Ltd, London, UK. pp. 357-379.

Serbian Regulation (1985): Pravilnik o kvalitetu zaklanih svinja i kategorizaciji svinjskog mesa. Službeni list SFRJ, 2/85, 20-30. (Rules on quality of slaughtered pigs and categorization of pig meat. Official Gazette of the SFRY, 2, 20-30.)

Spooncer, W.F. (1988): Organs and glands as human food. -in: Pearson, A.M. \& Dutson, T.R. (Eds): Edible meat by-products, Advances in meat research. Vol. 5, Elsevier Science Publishers Ltd, London, UK. pp. $197-217$.

STATSOFT, INC. (2011). STATISTICA (data analysis software system), version 10. available at: http://www.statsoft. com/.

Szabó, A., Horn, P., Romvári, R., HÁzas, Z. \& Fébel, H. (2010): Comparison of Mangalica and Hungarian Large White pigs at identical bodyweight: 2 . Fatty acid regiodistribution analysis of the triacylglycerols. Arch. Tierzucht, 53, 147-161.

The US Department of Agriculture's Nutrient Data Laboratory (2009): National Nutrient Database. Available at: http://ndb.nal.usda.gov/.

Tomović, V.M., Petrović, Lu.S., Tomović, M.S., Kevrešan, Ž.S. \& Džinić, N.R. (2011): Determination of mineral contents of semimembranosus muscle and liver from pure and crossbred pigs in Vojvodina (northern Serbia). Food Chem., 124, 342-348.

Tomović, V., Petrović, Lj., Jokanović, M., Tomović, M., Kevrešan, Ž., Tasić, T., Ikonić, P., Šojić, B., Škaljac, S. \& Šošo, M. (2013): Mineral concentration of the kidney in ten different pig genetic lines from Vojvodina (northern Serbia). Acta Alimentaria, 42, 198-207.

Tomović, V.M., ŽLender, B.A., Jokanović, M.R., Tomović, M.S., Šojić, B.V., ŠKaljac, S.B., KevreŠan, Ž.S., Tasić, T.A., Ikonić, P.M. \& Šošo, M.M. (2014): Sensory, physical and chemical characteristics of meat from freerange reared Swallow-Belly Mangalica pigs. J. Anim. Plant. Sci., 24, 704-713. 